Article

\title{
Improved Performances of SiBCN Powders Modified Phenolic Resins-Carbon Fiber Composites
}

\author{
Wenjie Yuan ${ }^{1,2}$, Yang Wang ${ }^{1,2}$, Zhenhua Luo ${ }^{1,2}$, Fenghua Chen ${ }^{1,2, *}$, Hao Li ${ }^{1,2, *}$ and Tong Zhao ${ }^{1,2, *}$ \\ 1 Key Laboratory of Science and Technology on High-tech Polymer Materials, Institute of Chemistry, \\ Chinese Academy of Sciences, Beijing 100190, China; yuanwenjie@iccas.ac.cn (W.Y.); \\ wangyang2018@iccas.ac.cn (Y.W.); z.h.luo@iccas.ac.cn (Z.L.) \\ 2 School of Chemical Science, University of Chinese Academy of Sciences, Beijing 100049, China \\ * Correspondence: fhchen@iccas.ac.cn (F.C.); lihao306@iccas.ac.cn (H.L.); tzhao@iccas.ac.cn (T.Z.)
}

check for updates

Citation: Yuan, W.; Wang, Y.; Luo, Z.; Chen, F.; Li, H.; Zhao, T. Improved Performances of SiBCN Powders Modified Phenolic Resins-Carbon Fiber Composites. Processes 2021, 9, 955. https://doi.org/10.3390/ pr9060955

Academic Editor: Mainul Islam

Received: 1 April 2021

Accepted: 7 May 2021

Published: 28 May 2021

Publisher's Note: MDPI stays neutral with regard to jurisdictional claims in published maps and institutional affiliations.

Copyright: (c) 2021 by the authors. Licensee MDPI, Basel, Switzerland. This article is an open access article distributed under the terms and conditions of the Creative Commons Attribution (CC BY) license (https:// creativecommons.org/licenses/by/ $4.0 /)$.

\begin{abstract}
The effect of SiBCN powder on properties of phenolic resins and composites was analyzed. Compared with phenolic resins, the thermal stability of SiBCN powder modified phenolic resins (the SiBCN phenolic resins) by characterization of thermogravimetric analysis (TGA) improved clearly. It was found by X-ray photoelectron spectroscopy (XPS) that reactions between SiBCN powder and the pyrolysis product of phenolic resins were the main factor of the increased residual weight. TGA and static ablation of a muffle furnace were used to illustrate the roles of SiBCN powder on increasing oxidation resistance of $\mathrm{SiBCN}$ powder-modified phenolic resin-carbon fiber composites (SiBCN-phenolic/C composites), and the oxidative product was analyzed by $\mathrm{X}$-ray diffraction (XRD), scanning electron microscopy (SEM) and Fourier transform infrared spectroscopy (FTIR). For $\mathrm{SiBCN}$-phenolic/C composites, the occurrence of oxidation reaction and the formation of protective crust contributed to improving oxidative resistance. The result of the oxygen-acetylene test showed that the linear ablation rate (LAR) and mass ablation rate (MAR) of phenolic resin-carbon fiber composites reduced from $0.052 \pm 0.005 \mathrm{~mm} / \mathrm{s}$ to $0.038 \pm 0.004 \mathrm{~mm} / \mathrm{s}$ and from $0.050 \pm 0.004 \mathrm{~g} / \mathrm{s}$ to $0.043 \pm 0.001 \mathrm{~g} / \mathrm{s}$ by introducing $\mathrm{SiBCN}$ powder, respectively. The mechanism of ablation resistance after the introduction of SiBCN powder was investigated. The high melt-viscosity of SiBCN powder caused SiBCN powder to remain on the surface of composites and protect the internal resins and carbon fibers. The oxidation of SiBCN powder and volatilization of oxide can consume energy and oxygen, thus the ablation resistance of SiBCN-Ph composite was improved.
\end{abstract}

Keywords: SiBCN powder; phenolic resin-carbon fiber composites; thermal stability; oxidation resistance; ablative resistance

\section{Introduction}

Phenolic resin-carbon fiber composites with excellent thermal stability, dimensional stability, mechanical properties, lightweight, and ablation properties are regarded as effective thermal protection material to protect space vehicles in the high temperature aerobic environment [1]. With the rapid development of aerospace craft, the applied environment becomes harsh and a large area of the craft must face a high temperature $\left(>1000^{\circ} \mathrm{C}\right)$ aerobic environment for a long time [2]. However, phenolic resins with poor oxidation resistance difficultly meet the requirements of long-term application under high temperature and aerobic conditions [3,4]. Thus, it is urgent to improve the performance of phenolic resin-carbon fiber composites [5].

In recent years, different kinds of inorganic powder [6,7] had been used to improve the ablation resistance, thermal stability and other properties of phenolic resins. L Asaro [8] and his co-workers studied the influence of the introduction of mesoporous silica particles on the ablative properties of phenolic/carbon fiber composites. The composite with $20 \mathrm{wt} \%$ silica particle loadings had the lowest mass erosion rate, because the melted silica can remain 
above the carbon fibers to protect the surface of the material during ablation. Kandasubramanian Balasubramanian group [9] introduced boron nitride to reinforce phenolic-carbon fiber composites, and composites with $3 \mathrm{wt} \% \mathrm{BN}$ loadings showed maximum improvement of ablation performance. Performance enhancement resulted from phase transformation of $\mathrm{h}-\mathrm{BN}$ at higher temperatures and typical floral assimilation which can lead to significant energy consumption. Zahra Amirsardari [10] and his coworkers found that the introduction of nanosized $\mathrm{ZrB}_{2}$ powder could improve the ablative properties of phenolic/carbon fiber composites in terms of mass loss and erosion rate. Jie Ding [11,12] provided an effective way to modify phenolic resins by the addition of $\mathrm{ZrSi}_{2}$, which prominently improved the ablation performance of phenolic-carbon fiber composites by the formation of $\mathrm{ZrO}_{2}$ and $\mathrm{SiO}_{2}$. Zhaofeng Chen [1] etc. thought that SiC-modified phenolic resins/carbon fiber composites are a kind of great potential thermal structural material in aeronautics and astronautics with low specific weight, good thermal stability, oxidation resistance and excellent ablation resistance. In general, the introduction of inorganic powder was frequently utilized to improve the performance of phenolic-carbon fiber composites [13].

Polymer-derived silicon-boron-carbon-nitrogen $(\mathrm{SiBCN})$ quaternary system ceramic (PDCs) have an amorphous structure and steady three-dimensional network structure formed by a strong covalent bond, which draws widespread addition [14,15]. Amorphous SiBCN contains three main chemical structures: (1) amorphous carbon clusters ("free" or $\mathrm{sp}^{2}$-carbon) in nanoscale, (2) BN(C) phase, and (3) an amorphous Si-C-N matrix consisted of SiC, Si3N4 and SiCxNy $[15,16]$. The special structure endowed SiBCN ceramics with extremely high thermal structural stability $[14,17]$. SiBCN ceramics still have excellent creep resistance in the range of $1400 \sim 1500{ }^{\circ} \mathrm{C}$. The viscosity coefficient of $\mathrm{SiBCN}$ ceramics is about $10^{15} \mathrm{~Pa} \cdot \mathrm{s}$ at $1550{ }^{\circ} \mathrm{C}$, which is an order of magnitude higher than that of fused silica [18]. SiBCN ceramics have better oxidation resistance at temperatures up to $1800^{\circ} \mathrm{C}$, compared with traditional $\mathrm{SiC}\left(>1600^{\circ} \mathrm{C}\right)$ and $\mathrm{Si}_{3} \mathrm{~N}_{4}\left(>1500^{\circ} \mathrm{C}\right)$ ceramics [14,16]. Moreover, the density of SiBCN powder was $1.87 \mathrm{~g} / \mathrm{cm}^{3}$ (same as carbon fibers) and lower than most ceramics, which contributed to alleviate the weight of the composites [17]. Therefore, $\mathrm{SiBCN}$ ceramic powder could be used to modify the performance of phenolic resins-carbon fiber (Carbon/phenolic) composites as suitable inorganic powder.

Although $\mathrm{SiBCN}$ powder has excellent properties, $\mathrm{SiBCN}$ powder never is introduced into resin matrix composites to improve comprehensive performance. In this paper, we prepared SiBCN phenolic resins and SiBCN-phenolic/C composites. The residue constituents of $\mathrm{SiBCN}$ phenolic resins after pyrolysis were also investigated, and the effects of the introduction of SiBCN powder on the thermal stability and degradation behavior of $\mathrm{SiBCN}$ phenolic resins were analyzed. The roles of $\mathrm{SiBCN}$ particles on oxidation resistance and ablation resistance of $\mathrm{SiBCN}$-phenolic/C composites were studied. Changes in chemical structure and microstructure of the ablated specimens were researched to discuss the oxidative and ablative mechanisms.

\section{Experimental}

\subsection{Materials}

Resole-type phenolic resins, the matrix of composites, were synthesized in our laboratory according to the literature [3]. Ethanol (Sinopharm Chemical Reagent Co., Beijing, China) was used as the solvent. Plain weave carbon fiber cloth (T300, Japan Toray Company, Tokyo, Japan) was used as reinforcement of composites. SiBCN powder with the amorphous structure was prepared in our laboratory according to the literature $[16,19]$.

\subsection{Sample Preparation}

2.2.1. Fabrication Process of SiBCN-Modified Phenolic Resins (the SiBCN Phenolic Resins)

Phenolic resins $(\mathrm{Ph})$ were mixed with $\mathrm{SiBCN}$ powder in the mass proportion of 1:0.1 by mechanical stirring and ultrasonic dispersion to prepare $\mathrm{SiBCN}$ modified phenolic resin (the SiBCN phenolic resins). The SiBCN phenolic resins were cured at $80^{\circ} \mathrm{C}$ for $4 \mathrm{~h}$, 
followed by $120^{\circ} \mathrm{C}$ for $2 \mathrm{~h}$, and then $180^{\circ} \mathrm{C}$ for $4 \mathrm{~h}$, all in an oven. Finally, the cured SiBCN phenolic resins were obtained.

2.2.2. Fabrication Process of SiBCN-Modified Phenolic Resin-Carbon Fiber Composites (SiBCN-Phenolic/C Composites)

SiBCN powder was added to the phenolic resin/ethanol solution (50 wt \%) by mechanical stirring for $2 \mathrm{~h}$, and the SiBCN-phenolic ethanol mixture solution was obtained. The mass proportion of phenolic resins, ethanol and SiBCN powder was 1:1:0.1 in the solution. Plain weave carbon fiber cloth was coated with the above mixture, the weight ratio of carbon fiber and hybrid resins was 1:1. Then, the impregnated clothes were put in the fume hood at ambient temperature for $12 \mathrm{~h}$ to evaporate the solvent and put in the oven at $80{ }^{\circ} \mathrm{C}$ for $60 \mathrm{~min}$. Then the prepared prepregs were cut into $100 \times 100 \mathrm{~mm}$ pieces, put in the mold and pressed on the hot plate under the pressure of $30 \mathrm{~kg} \cdot \mathrm{cm}^{-2}$ at $120^{\circ} \mathrm{C}$ for $2 \mathrm{~h}$ and $180{ }^{\circ} \mathrm{C}$ for $4 \mathrm{~h}$, and the laminated board was obtained. Finally, the SiBCN-phenolic/C composites were fabricated into cylindrical samples with sizes of $\Phi 30 \times 10 \mathrm{~mm}$ (a diameter of $30 \mathrm{~mm}$ and a thickness of $10 \mathrm{~mm}$ ) for the oxygen-acetylene ablation testing. The fabrication process of phenolic/C composites was the same as that of SiBCN-phenolic/C composites.

\subsection{Characterization and Testing}

Fourier transform infrared spectroscopy (FTIR) measurements were performed on a Tensor-27 spectrometer at room temperature. Samples were ground, mixed with $\mathrm{KBr}$ (the weight ratio of sample and $\mathrm{KBr}$ was 1:100) and pressed into small flakes for testing. The number of sample scans was 16 and the resolution was 4 . Thermogravimetric Analysis (TGA) was carried out from ambient temperature to $1200{ }^{\circ} \mathrm{C}$ on a Netzsch STA409PC at a heating rate of $10^{\circ} \mathrm{C} \cdot \mathrm{min}^{-1}$ in nitrogen and air atmosphere, respectively. The form of the sample was powder (particle size: $300 \sim 450 \mu \mathrm{m}$ ), mass of the samples was $6 \sim 8 \mathrm{mg}$, flow rate of carrier gas was $50 \mathrm{~mL} / \mathrm{min}$ and flow rate of purge gas was $15 \mathrm{~mL} / \mathrm{min}$. The cured resins were pyrolyzed $2 \mathrm{~h}$ in a tube furnace at $1200{ }^{\circ} \mathrm{C}$ and volume shrinkage was defined as the volume ratio of the cured resins before and after pyrolysis. The number of replicates for each sample was 3. The cured phenolic resins and SiBCN phenolic resins were quenched and cracked in liquid nitrogen, and the fracture surface of the hybrids was observed on a Hitachi S-8020 scanning electron microscope (SEM) at an accelerating voltage of $10 \mathrm{kV}$. Energy-dispersive X-ray spectroscopy (EDS) was performed on Oxford INCAx-sight 7593 system attaching to the SEM apparatus. A high-temperature oxidation test was performed in a muffle furnace at the desired temperature with different times. The number of replicates for each sample was 3. The internal gas in a muffle was air and no gas entered after the start of the test. The oxyacetylene flame test was carried out to evaluate the mass ablative rate of the composite according to GB323A-96. At least three specimens with a dimension of approximately $\Phi 30 \mathrm{~mm}$ (diameter) $\times 10 \mathrm{~mm}$ (thickness) were prepared for each test, and the exposure time for each ablation test under the torch flame was $30 \mathrm{~s}$. The back temperature of the samples was measured with a K-type thermocouple. The average value was obtained for each sample. The chemical composition of the oxidized SiBCN phenolic resins was determined by X-ray photoelectron spectroscopy (XPS) measurement on an ESCALAB250XI instrument (Thermo Fisher Scientific, Waltham, MA, USA). One sample was tested for this characterization. The diameter of beam spot was $400 \mu \mathrm{m}$ and constant analyzer energy was 100.0, $1.00 \mathrm{eV}$. The obtained data were calibrated by C $1 \mathrm{~s}$ standard peak and analyzed by PEAK XPS software. The crystal structure of the SiBCN ceramics powder was characterized by X-ray diffraction (XRD, Bruker D8A A25, Karlsruhe, Germany) with $\mathrm{Cu} \mathrm{K} \alpha$ radiation at $40 \mathrm{kV}$ and $40 \mathrm{~mA}$. The diffraction patterns were scanned from $10^{\circ}$ to $80^{\circ}$ of $2 \theta$ in a step-scan mode at a step of $0.26^{\circ}$ and a counting time of $0.02 \mathrm{~s} / \mathrm{step}$. Particle size distribution was measured with a laser particle size analyzer (Mastersizer 3000, Malvern Instruments Ltd., Malvern, UK). 


\section{Results and Discussion}

3.1. Morphology of SiBCN Powder on the SiBCN Phenolic Resins and the SiBCN-Phenolic/C Composites

As shown in Figure 1a,b, SiBCN powder have a broad distribution of particle size $(\mathrm{D} 10=2.45 \mu \mathrm{m}, \mathrm{D} 50=21.7 \mu \mathrm{m}$ and D90 $=50.8 \mu \mathrm{m})$ and irregular shape. For the cured SiBCN phenolic resins (Figure 1c), powder was embedded in the resin matrix and tightly bound with resin. From Figure 1c, the dispersion of SiBCN powder was homogeneous. In Figure 1d,e, SiBCN powder with large particle sizes accumulated between the layers of carbon fiber fabric and SiBCN powder with small particle sizes can penetrate carbon fiber fabric after the preparation of SiBCN-phenolic/C composites. In addition, since the density of SiBCN powder was almost the same as carbon fibers and lower than normal metal/nonmetal oxide and carbide, the density of the SiBCN-phenolic $/ \mathrm{C}$ composite $\left(1.456 \mathrm{~g} / \mathrm{mm}^{3}\right)$ was not significantly higher than that of the phenolic composite $\left(1.451 \mathrm{~g} / \mathrm{mm}^{3}\right)$.
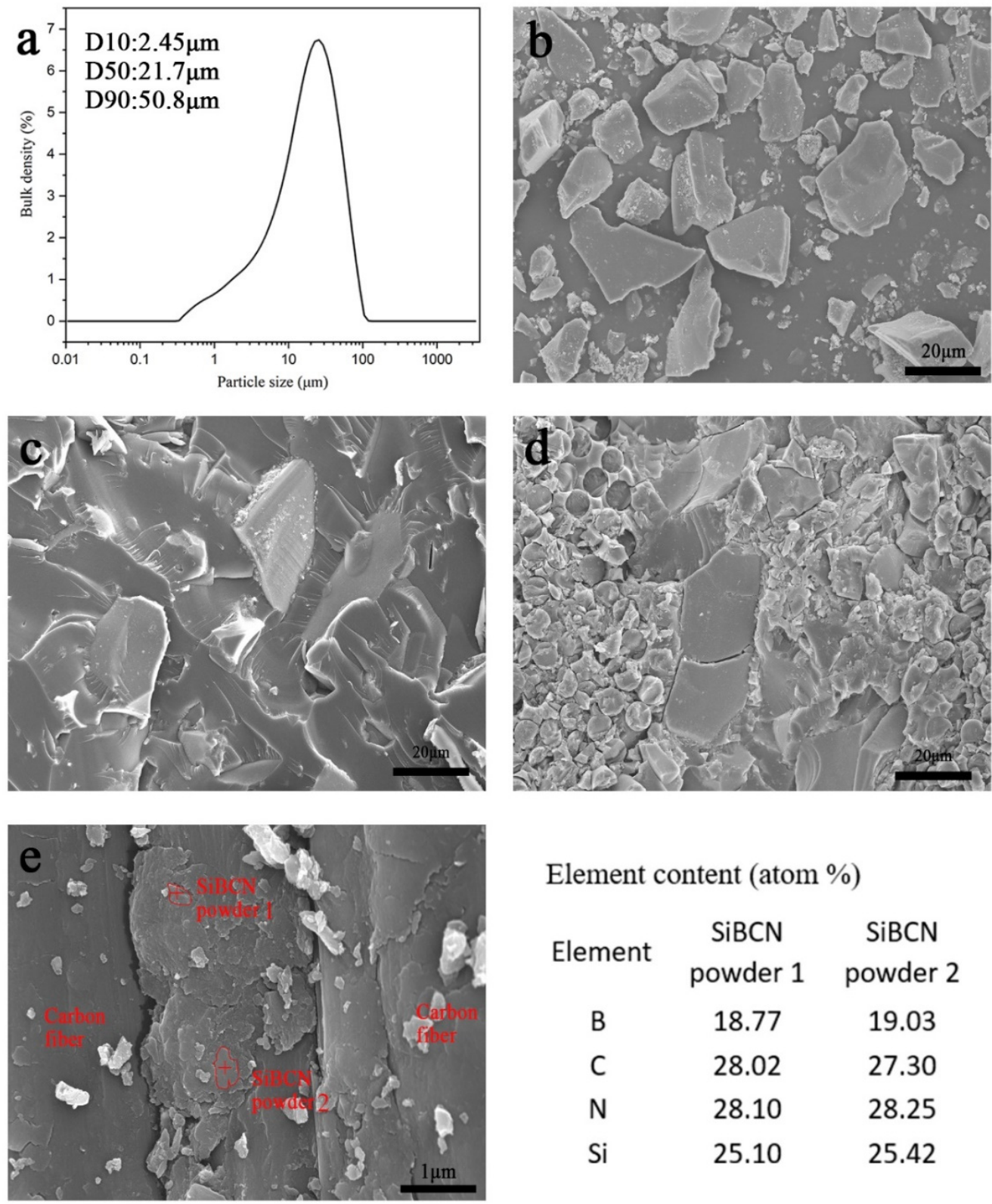

\section{Element content (atom \%)}

$\begin{array}{ccc}\text { Element } & \begin{array}{c}\text { SiBCN } \\ \text { powder 1 }\end{array} & \begin{array}{c}\text { SiBCN } \\ \text { powder 2 }\end{array} \\ \text { B } & 18.77 & 19.03 \\ \text { C } & 28.02 & 27.30 \\ \text { N } & 28.10 & 28.25 \\ \text { Si } & 25.10 & 25.42\end{array}$

Figure 1. Particle size distribution (a) and scanning electron microscopy (SEM) image (b) of SiBCN powder, SEM images of the cured SiBCN phenolic resins (c) and the SiBCN-phenolic/C composites $(\mathbf{d}, \mathbf{e})$. 


\subsection{Thermal Stability of the Cured SiBCN Phenolic Resins}

As shown in Figure 2, thermal stability of the cured phenolic resins and the cured $\mathrm{SiBCN}$ phenolic resins were studied by thermal gravimetric analysis. The thermal stability of phenolic resins was improved by the introduction of $\mathrm{SiBCN}$ powder. At the first stage $\left(<300{ }^{\circ} \mathrm{C}\right)$, according to reported papers, the release of water and other small molecule products was the main cause of weight loss [20]. It was found from Table 1 that $\mathrm{T}_{5 \%}$ and $\mathrm{R}_{300}$ increased slightly, which indicated that the introduction of $\mathrm{SiBCN}$ powder made phenolic resins gain a small improvement in thermal stability because of the thermal stability of SiBCN powder. At the second stage $\left(300 \sim 800{ }^{\circ} \mathrm{C}\right)$, rapid weight loss occurred with the release of low molecular weight phenolic and aromatic compounds and other low molecular weight hydrocarbons $\left(\mathrm{CO}, \mathrm{CO}_{2}, \mathrm{CH}_{4}, \mathrm{H}_{2} \mathrm{O}, \mathrm{H}_{2}, \mathrm{CH}_{4}, \mathrm{C}_{2} \mathrm{H}_{2}, \mathrm{C}_{2} \mathrm{H}_{6}\right)$ produced by pyrolysis [11]. Almost the same $\mathrm{T}_{\max }$ showed that the introduction of powder did not change the thermal pyrolysis behavior of resins. However, the difference in the residual weight between the cured $\mathrm{SiBCN}$ phenolic resins and the cured phenolic resins was growing in this stage. The residual weight difference increased from $1.07 \%$ at $300{ }^{\circ} \mathrm{C}$ to $5.15 \%$ at $800^{\circ} \mathrm{C}$. For the third stage $\left(>800^{\circ} \mathrm{C}\right)$, the weight loss of phenolic resins slowed down at $800 \sim 900^{\circ} \mathrm{C}$, and then the weight loss accelerated. The cured SiBCN phenolic resins had the same trend, but its duration of the stage with slow weight loss rate was longer than phenolic resins. Assuming no interactions between the powder and the resin, theoretical residual weight of the cured $\mathrm{SiBCN}$ phenolic resins could be calculated according to the residual weight of phenolic resins and SiBCN powder during the thermal pyrolysis process. Theoretical residual weight of the cured $\mathrm{SiBCN}$ phenolic resins and the actual residual weight were almost the same at $300{ }^{\circ} \mathrm{C}$. However, theoretical residual weight of the cured SiBCN phenolic resins at $1200{ }^{\circ} \mathrm{C}$ should theoretically be $59.70 \%$, but the actual residual weight of that was $62.98 \%$. The $3.28 \%$ promotion may have been caused by the reaction between $\mathrm{SiBCN}$ powder and phenolic resin during the pyrolysis process.

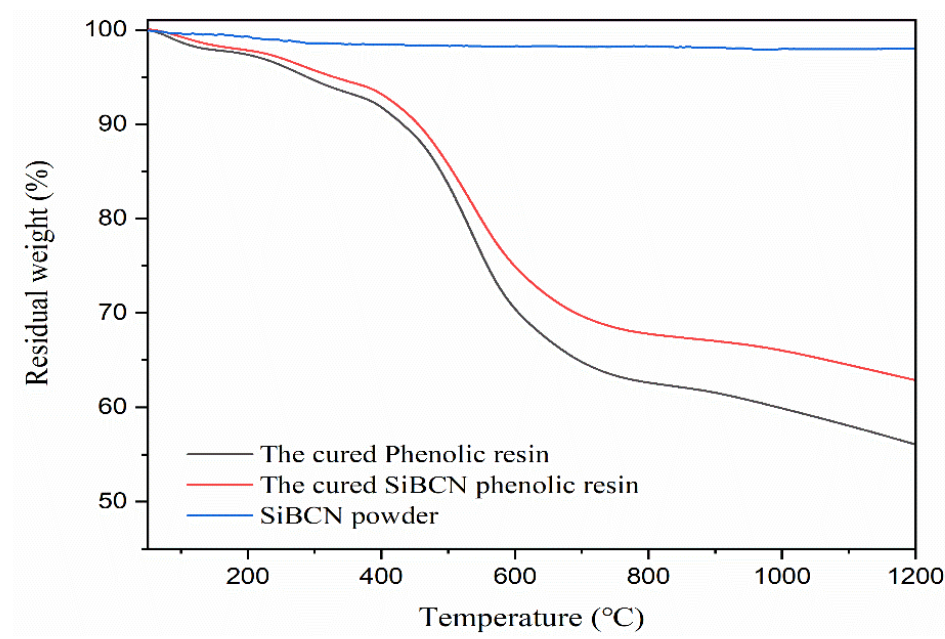

Figure 2. Thermogravimetric (TG) curves of the cured phenolic resins and the cured SiBCN phenolic resins in $\mathrm{N}_{2}$ atmosphere.

Table 1. Thermogravimetric analysis (TGA) results under $\mathrm{N}_{2}$ atmosphere of the cured phenolic resins and the cured SiBCN phenolic resins.

\begin{tabular}{|c|c|c|c|c|c|c|}
\hline Samples & $\mathrm{T}_{5 \%}\left({ }^{\circ} \mathrm{C}\right)^{\mathrm{a}}$ & $\mathrm{T}_{\max }\left({ }^{\circ} \mathrm{C}\right)^{\mathrm{b}}$ & $R_{300}(\%)^{c}$ & $R_{800}(\%)^{d}$ & $R_{1000}(\%)^{e}$ & $R_{1200}(\%)^{f}$ \\
\hline The cured phenolic resins & 288.67 & 541.07 & 94.64 & 62.62 & 59.89 & 55.87 \\
\hline SiBCN powder & $\backslash$ & 1 & 98.59 & 98.24 & 97.98 & 98.01 \\
\hline The cured SiBCN-phenolic resins & 329.18 & 545.65 & 95.71 & 67.77 & 66.02 & 62.98 \\
\hline $\begin{array}{l}\text { Theoretical residual weight of } \\
\text { SiBCN phenolic resins }\end{array}$ & $\backslash$ & 1 & 95.00 & 65.86 & 63.35 & 59.70 \\
\hline
\end{tabular}

a The temperature of the $5 \%$ weight loss. ${ }^{\mathrm{b}}$ The temperature of the maximum degradation rate. ${ }^{\mathrm{c}}$ Residue yield at $300{ }^{\circ} \mathrm{C} .{ }^{\mathrm{d}}$ Residue yield at

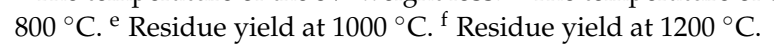


XPS was used to analyze the chemical compositions of the cured SiBCN phenolic resins after pyrolyzed $2 \mathrm{~h}$ (ensure complete pyrolysis) at $1200^{\circ} \mathrm{C}$ in $\mathrm{Ar}$ (consistent with the thermogravimetric environment). As can be seen in Figure 3a, two peaks were displayed on the Si element spectrum of $\mathrm{SiBCN}$ powder: (1) $101.80 \mathrm{eV}: \mathrm{Si}_{3} \mathrm{~N}_{4}\left(\mathrm{Si}_{2} \mathrm{p}_{3 / 2}\right)$ [21]; (2) $102.60 \mathrm{eV}$ : $\mathrm{SiC}(\mathrm{SiC} / \mathrm{BN})\left(\mathrm{Si} 2 \mathrm{p}_{3 / 2}\right)$ [22], which indicated that amorphous Si-C-N matrix contained the $\mathrm{Si}_{3} \mathrm{~N}_{4}$ phase and $\mathrm{SiC}$ phase. However, four peaks were shown in the Figure $3 \mathrm{~b}$ : (1) $101.50 \mathrm{eV}$ : $\mathrm{Si}_{3} \mathrm{~N}_{4}\left(\mathrm{Si} 2 \mathrm{p}_{3 / 2}\right)$ [23]; (2) $102.40 \mathrm{eV}: \mathrm{SiC}(\mathrm{SiC} / \mathrm{BN})\left(\mathrm{Si} \mathrm{2p_{3/2 }}\right.$ ) [24]; (3) $100.10 \mathrm{eV}: \mathrm{SiC}$ (Si 2p) [22]; (4) $103.20 \mathrm{eV}: \mathrm{SiO}_{2} / \mathrm{SiC}\left(\mathrm{Si} 2 \mathrm{p}_{3 / 2}\right)$ [25]. The appearance of peak $103.20 \mathrm{eV}$ indicated that $\mathrm{SiO}_{2}$ produced in pyrolysis progress by the reaction $[1,15,21]$ :

$$
\begin{aligned}
& \mathrm{Si}_{3} \mathrm{~N}_{4}(\mathrm{~s})+3 \mathrm{CO}_{2}(\mathrm{~g}) \rightarrow 3 \mathrm{SiO} 2(\mathrm{~s})+3 \mathrm{C}(\mathrm{s})+2 \mathrm{~N}_{2}(\mathrm{~g}) \\
& \mathrm{Si}_{3} \mathrm{~N}_{4}(\mathrm{~s})+6 \mathrm{CO}(\mathrm{g}) \rightarrow 3 \mathrm{SiO}_{2}(\mathrm{~s})+6 \mathrm{C}(\mathrm{s})+2 \mathrm{~N}_{2}(\mathrm{~g}) \\
& \mathrm{Si}_{3} \mathrm{~N}_{4}(\mathrm{~s})+6 \mathrm{H}_{2} \mathrm{O}(\mathrm{g}) \rightarrow 3 \mathrm{SiO}_{2}(\mathrm{~s})+3 \mathrm{H}_{2}(\mathrm{~g}) \uparrow+2 \mathrm{~N}_{2}(\mathrm{~g}) \\
& \mathrm{SiC}(\mathrm{s})+2 \mathrm{H}_{2} \mathrm{O}(\mathrm{g}) \rightarrow \mathrm{SiO}_{2}(\mathrm{~s})+\mathrm{CH}_{4}(\mathrm{~g}) \\
& \mathrm{SiC}(\mathrm{s})+3 \mathrm{CO}_{2}(\mathrm{~g}) \rightarrow \mathrm{SiO}_{2}(\mathrm{~s})+4 \mathrm{CO}(\mathrm{g})
\end{aligned}
$$

In Figure 3c, two peaks were displayed on the B element spectrum of SiBCN: (1) 190.60 eV: BN (B 1 s) [26]; (2) $192.40 \mathrm{eV}: \mathrm{BCN}$ (B 1 s) [27], which meant that BN(C) phase consisted of $\mathrm{BN}$ phase and $\mathrm{BCN}$ phase. However, the peak of $192.40 \mathrm{eV}$ had disappeared and the peak of $192.70 \mathrm{eV}$ (BNO (B 1 s)) [28] appeared in Figure 3d, which indicated that the boride of $\mathrm{SiBCN}$ was oxidized in the pyrolysis progress [9].

$2 \mathrm{BN}(\mathrm{s})+\mathrm{CO}_{2}(\mathrm{~g}) \rightarrow 2 \mathrm{BNO}(\mathrm{s})+\mathrm{C}(\mathrm{s})$

$2 \mathrm{BCN}(\mathrm{s})+\mathrm{CO}_{2}(\mathrm{~g}) \rightarrow 2 \mathrm{BNO}(\mathrm{s})+3 \mathrm{C}(\mathrm{s})$

Reactions of boride and silicide during pyrolysis processes made carbon and oxygen elements of volatiles remain in the matrix with the formation of the $\mathrm{BNO}, \mathrm{SiO}_{2}$ and $\mathrm{C}$. The occurrence of these reactions increased the residual weight and enhanced the thermal stability of SiBCN phenolic resins at high temperature.
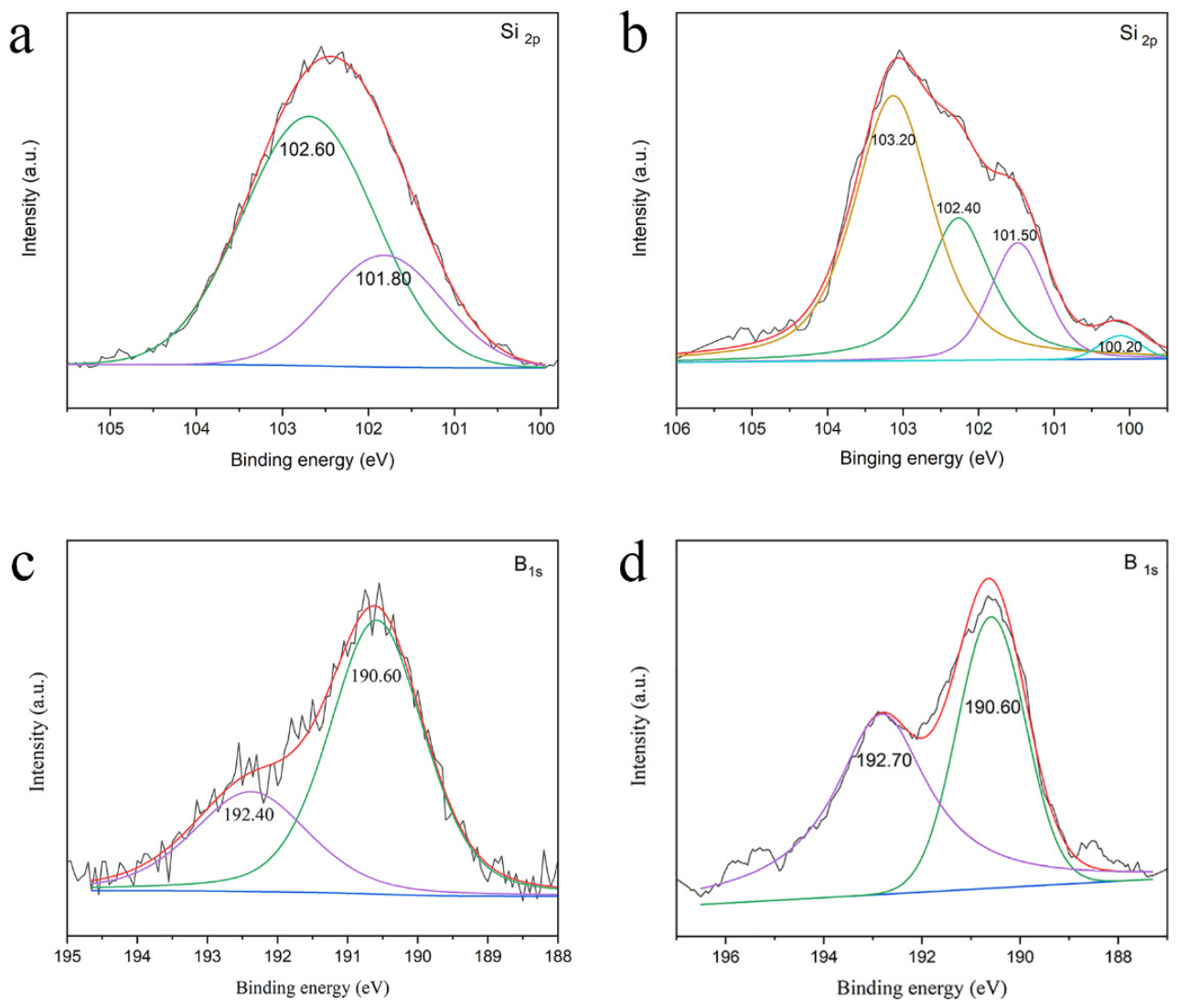

Figure 3. $\mathrm{Si}_{2 p}$ spectra of $\mathrm{SiBCN}$ powder (a) and the pyrolyzed $\mathrm{SiBCN}$ phenolic resins at $120{ }^{\circ} \mathrm{C}$ in Ar atmosphere (b), $B_{1 s}$ spectra of $\operatorname{SiBCN}$ powder (c) and the pyrolyzed SiBCN phenolic resins at $1200{ }^{\circ} \mathrm{C}$ in Ar atmosphere (d). 
After $2 \mathrm{~h}$ pyrolysis at $1200{ }^{\circ} \mathrm{C}$ in an Aar atmosphere, the cured SiBCN phenolic resins shrunk but did not crack. Compared to the volume shrinkage ratio of phenolic resins $(31.11 \%)$, that of cured $\mathrm{SiBCN}$ phenolic resins was $24.31 \%$, which indicated that the introduction of $\mathrm{SiBCN}$ powder contributed to enhancing the dimensional stability. Because $\mathrm{SiBCN}$ ceramic with excellent dimensional stability can restrain shrinkage of phenolic resins at pyrolysis process. As shown in Figure 4, the fracture morphology of the pyrolyzed SiBCN phenolic resins $\left(1200{ }^{\circ} \mathrm{C}, 2 \mathrm{~h}\right)$ was observed by SEM and the element content of $\mathrm{SiBCN}$ powder surface was analyzed by EDS. The result illustrated that $\mathrm{SiBCN}$ powder reacted with the pyrolysis atmosphere of phenolic resin to generate oxides on the surface of the powder.

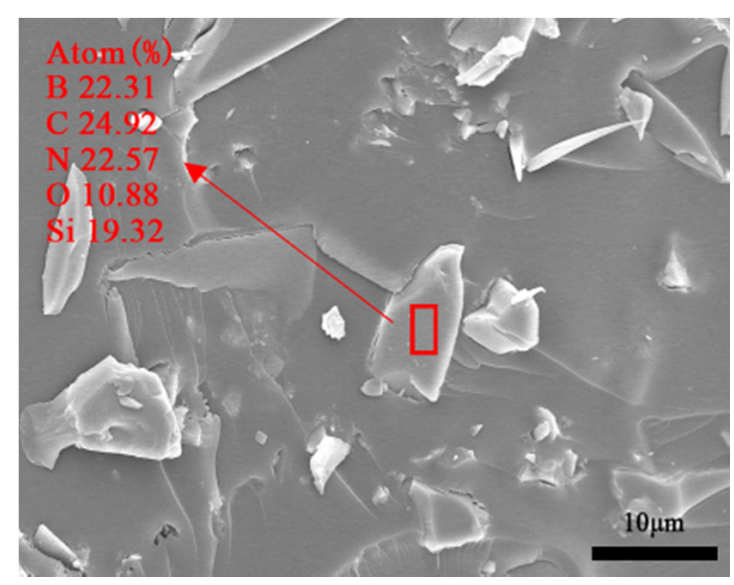

Figure 4. SEM image of the SiBCN phenolic resins after pyrolyzed $2 \mathrm{~h}$ at $1200{ }^{\circ} \mathrm{C}$ in $\mathrm{Ar}$ atmosphere.

\subsection{Oxidation Resistance of the Cured SiBCN Phenolic Resins}

As shown in Figure 5 and Table 2, TG curves of the cured phenolic resins and the cured $\mathrm{SiBCN}$ phenolic resins in air atmosphere demonstrated that at the temperature of $5 \%$ weight loss, the maximum degradation rate and the temperature of final decomposition of the cured $\mathrm{SiBCN}$ phenolic resins were both improved by the introduction of SiBCN. The residual weight of the cured phenolic resins and $\mathrm{SiBCN}$ powder at $800{ }^{\circ} \mathrm{C}$ was $0.76 \%$ and $97.43 \%$, respectively. If phenolic resins are oxidized completely, the residual weight of the cured $\mathrm{SiBCN}$ phenolic resins should be $8.86 \%$ (the amount of introduced $\mathrm{SiBCN}$ powder was $9.09 \%$ ). However, the residual weight of $\mathrm{SiBCN}$ phenolic resins at $800{ }^{\circ} \mathrm{C}$ was $13.31 \%$. It was obvious that the introduction of $\mathrm{SiBCN}$ powder can enhance the oxidation resistance.

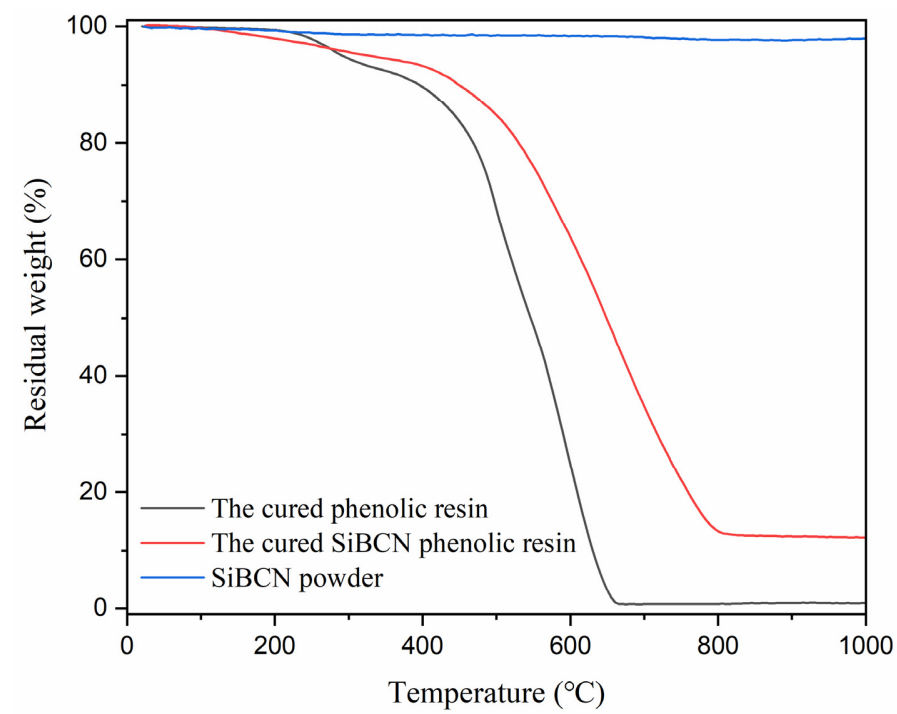

Figure 5. TG curves of the cured phenolic resins and the cured $\mathrm{SiBCN}$ phenolic resins in air atmosphere. 
Table 2. TGA results under air atmosphere of the cured phenolic resins and the cured SiBCN modified phenolic resins.

\begin{tabular}{ccccc}
\hline Samples & $\mathbf{T}_{\mathbf{5 \%}}\left({ }^{\circ} \mathbf{C}\right)^{\mathbf{a}}$ & $\mathbf{T}_{\max }\left({ }^{\circ} \mathbf{C}\right)^{\mathbf{b}}$ & $\mathbf{T}_{\text {end }}\left({ }^{\circ} \mathbf{C}\right)^{\mathbf{c}}$ & $\mathbf{R}_{\mathbf{8 0 0}}(\mathbf{\%})^{\mathbf{d}}$ \\
\hline The cured phenolic resins & 291.7 & 591.4 & 652.9 & 0.76 \\
SiBCN powder & $\backslash$ & $\backslash$ & $\backslash$ & 97.43 \\
The cured SiBCN phenolic resins & 328.0 & 647.1 & 774.3 & 13.31 \\
\hline
\end{tabular}

a The temperature of the $5 \%$ weight loss. ${ }^{\mathrm{b}}$ The temperature of the maximum degradation rate. ${ }^{\mathrm{c}}$ The temperature of final decomposition ${ }^{\mathrm{d}}$ Residue yield at $800^{\circ} \mathrm{C}$.

Subsequently, the chemical structure of residual SiBCN phenolic resins after being oxidized for $2 \mathrm{~h}$ (to ensure complete oxidation) at $1000^{\circ} \mathrm{C}$ in air (consistent with the thermogravimetric environment) was analyzed by XRD (Figure 6a) and Fourier transform infrared (FTIR) spectroscopy (Figure 6b). The patterns of XRD shown in Figure 6a illustrated SiBCN powder was slightly oxidized to generate $\mathrm{B}_{2} \mathrm{O}_{3}$ in the oxidation process [29]. Besides, as shown in the FTIR spectrum (Figure 6b), the absorption bands appearing at $1085 \mathrm{~cm}^{-1}$ and $1476 \mathrm{~cm}^{-1}$ were attributed to Si-O-Si and B-O-B. The appearance of these signals indicated that SiBCN powder was oxidized. Two signals located at $884 \mathrm{~cm}^{-1}$ and $677 \mathrm{~cm}^{-1}$ that belonged to Si-O-B illustrated that borosilicate might be generated during oxidation progress. Peaks at around $918 \mathrm{~cm}^{-1}$ and $787 \mathrm{~cm}^{-1}$ were ascribed to $\mathrm{Si}-\mathrm{N}$ and $\mathrm{Si}-\mathrm{C}$, which meant that the powder was not oxidized completely.
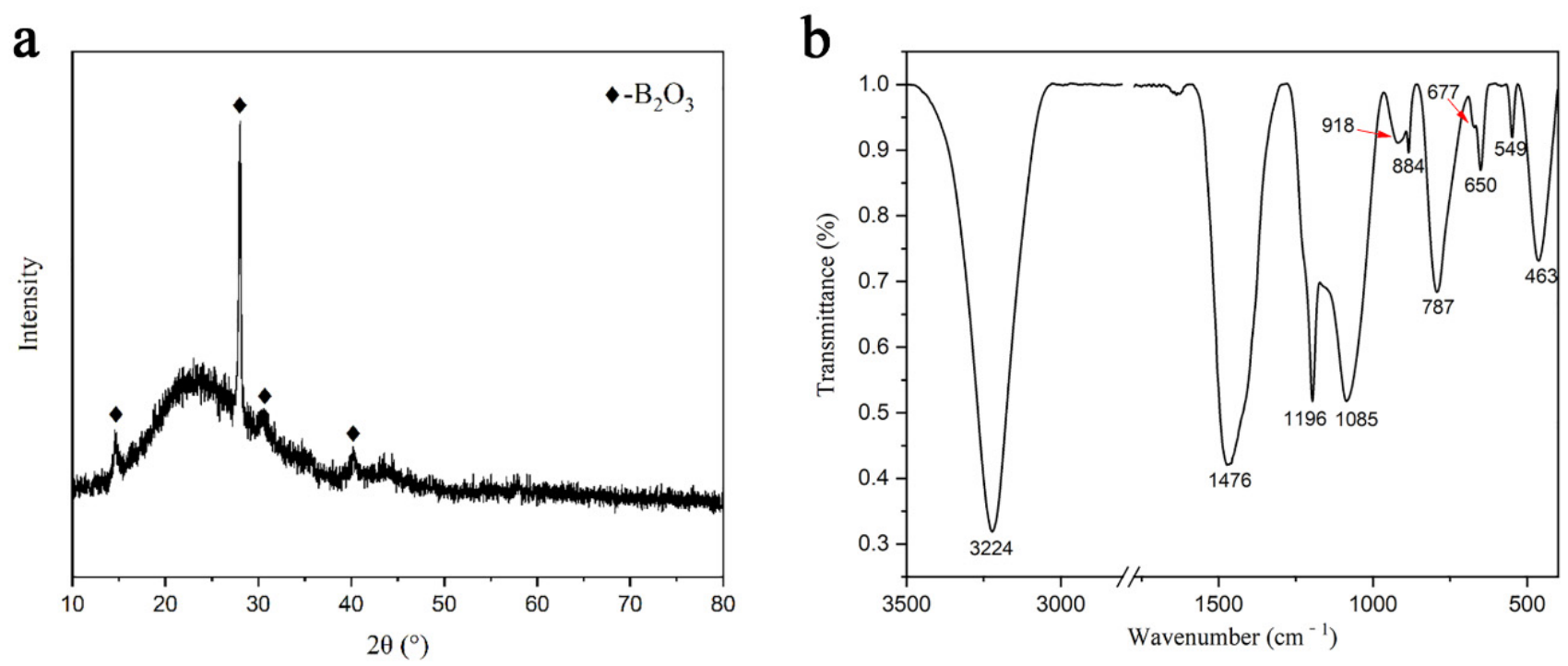

Figure 6. X-ray diffraction (XRD) pattern (a) and the Fourier transform infrared (FTIR) spectrum (b) of the SiBCN phenolic resins after oxidized in the muffle furnace at $1000^{\circ} \mathrm{C}$.

\subsection{Oxidation Resistance of SiBCN-Phenolic/C Composites}

A static ablation test in the muffle furnace was used to further study the influence of the $\mathrm{SiBCN}$ powder on the oxidation resistance of composites. Figure 7a showed the residual weight of phenolic composites and the SiBCN-phenolic/C composites after oxidization at different temperatures for $1 \mathrm{~h}$. In Figure $7 \mathrm{a}$, the residual weight of phenolic/C composites was almost equal to that of $\mathrm{SiBCN}$-phenolic/C composites after oxidized at $600{ }^{\circ} \mathrm{C}$. It was indicated that the oxidation reaction of phenolic resin was the main result of weight loss at $600{ }^{\circ} \mathrm{C}$. The residual weight of the SiBCN-phenolic/C composites was only $3.09 \%$ higher than that of phenolic composites after being oxidized for $1 \mathrm{~h}$ at $800^{\circ} \mathrm{C}$. When composites were tested $1 \mathrm{~h}$ at $1000{ }^{\circ} \mathrm{C}$, the residual weight of SiBCN-phenolic/C composites increased $31.42 \%$ (phenolic composites) to $40.67 \%$. With increasing oxidation temperature, the difference of residual weight between phenolic/C composites and SiBCN-phenolic/C 
composites became larger. Moreover, as shown in Figure $7 \mathrm{~b}$, the residual weight of SiBCNphenolic/C composites after being oxidized for $2 \mathrm{~h}$ at $800{ }^{\circ} \mathrm{C}$ increased from $30.76 \%$ (phenolic composites) to $46.19 \%$. However, the residual weight of phenolic/C composites and $\mathrm{SiBCN}$-phenolic/C composites was $53.92 \%$ and $57.01 \%$ after being oxidated for $1 \mathrm{~h}$ at $800{ }^{\circ} \mathrm{C}$, respectively. With the longer oxidation time, the residual weight gap between phenolic/C composites and SiBCN-phenolic/C composites was more obvious. This result indicated that the introduction of $\mathrm{SiBCN}$ powder contributed to improving the oxidation resistance of composites.
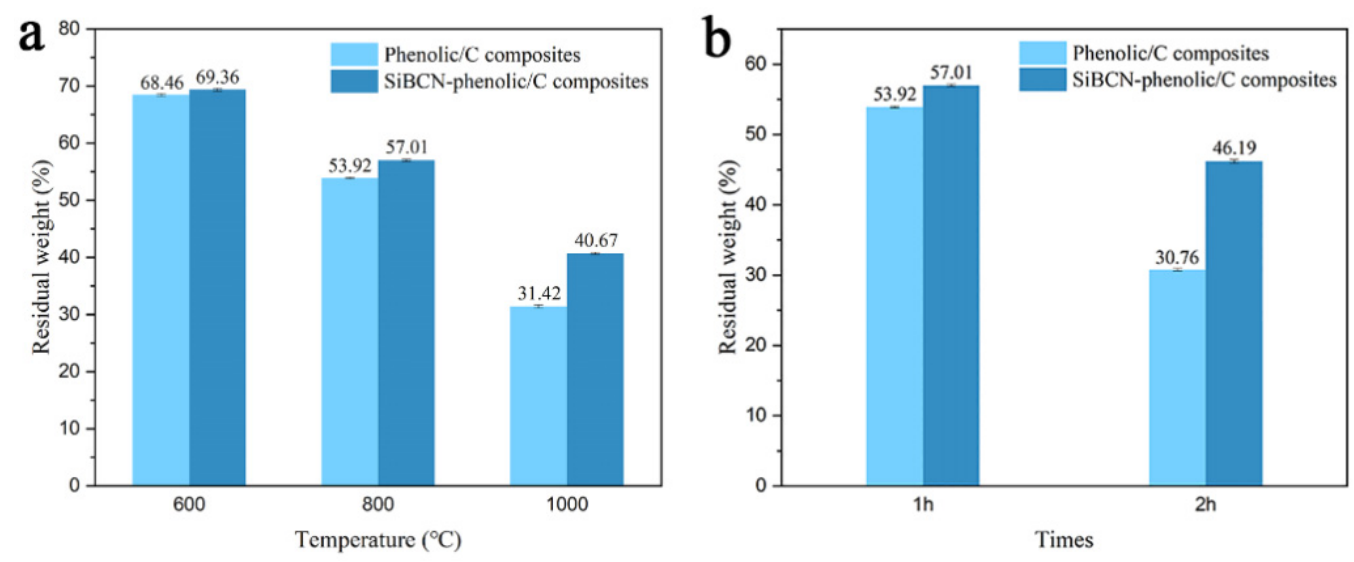

Figure 7. Residual weight of phenolic/C composites and SiBCN-phenolic/C composites at different temperatures for $1 \mathrm{~h}$ (a); residual weight of phenolic/C composites and SiBCN-phenolic/C composites at $800^{\circ} \mathrm{C}$ for different times (b).

When the SiBCN-phenolic/C composites and phenolic composites were oxidized $2 \mathrm{~h}$ at $1000{ }^{\circ} \mathrm{C}$ in a muffle oven, phenolic composites had no residue, but the residual weight of SiBCN-phenolic/C composites was still 7.1\%. As shown in Figure 8a,b, some carbon fibers remained at the bottom of $\mathrm{SiBCN}$-phenolic/C composites and the sectional fundamental framework of $\mathrm{SiBCN}$-phenolic/C composites was maintained after being oxidized. To further explore the reasons for this phenomenon, microstructure of SiBCNphenolic/C composites surface was analyzed by SEM (Figure 8c). It can be seen that the residual SiBCN powder and their oxide are connected to form a protective carapace that can slow down oxygen erosion of the internal matrix in the oxidation process. The oxidation resistance of $\mathrm{SiBCN}$-phenolic/C composites can be attributed to two aspects. First, the oxidation reaction of SiBCN powder and volatilization of oxide can consume oxygen and heat [10]. Second, the residual SiBCN powder and their oxide can form a protective carapace to prevent oxygen from eroding the internal matrix and carbon fibers.
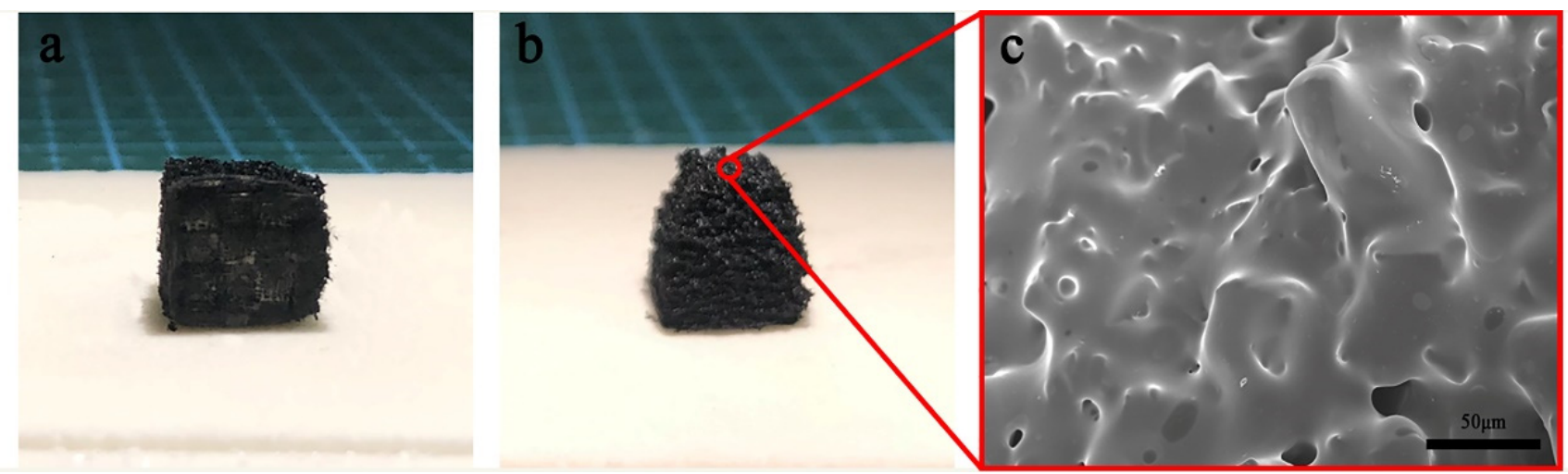

Figure 8. The picture of the SiBCN-phenolic/C composites oxidized $2 \mathrm{~h}$ at $1000{ }^{\circ} \mathrm{C}(\mathbf{a}, \mathbf{b})$ and SEM image of the surface of the $\mathrm{SiBCN}$-phenolic/C composites oxidized $2 \mathrm{~h}$ at $1000^{\circ} \mathrm{C}(\mathrm{c})$. 


\subsection{Ablation Resistance of the SiBCN-Phenolic/C Composites}

As depicted in Table 3, ablation properties were reflected by linear ablation rate (LAR) and mass ablation rate (MAR). The average LAR and MAR of phenolic/C composites were $0.052 \pm 0.005 \mathrm{~mm} / \mathrm{s}$ and $0.050 \pm 0.004 \mathrm{~g} / \mathrm{s}$, respectively. However, the introduction of SiBCN powder helped to decrease the average LAR and MAR of SiBCN-phenolic/C composites to $0.038 \pm 0.004 \mathrm{~mm} / \mathrm{s}$ and $0.043 \pm 0.001 \mathrm{~g} / \mathrm{s}$, respectively. The LAR of SiBCNphenolic/C composites reduced by $27 \%$ compared with that of phenolic/C composites, the MAR of SiBCN-phenolic/C composites reduced by $14 \%$. It was found that the ablation resistance of composites can be significantly improved by introducing $\mathrm{SiBCN}$ powder.

Table 3. Ablation properties of phenolic/C composites and SiBCN-phenolic/C composites.

\begin{tabular}{ccc}
\hline Samples & Linear Ablation Rate $(\mathbf{m m} / \mathbf{s})$ & Mass Ablation Rate $(\mathbf{g} / \mathbf{s})$ \\
\hline Phenolic/C composites & $0.052 \pm 0.005$ & $0.050 \pm 0.004$ \\
SiBCN-phenolic/C composites & $0.038 \pm 0.004$ & $0.043 \pm 0.001$ \\
\hline
\end{tabular}

To further study the mechanism of ablation performance improvement by the introduction of SiBCN powder, SEM was used to observe the microstructure of the ablated $\mathrm{Ph}$ and $\mathrm{SiBCN}$-phenolic/C composites. During the ablation process, the center temperature of the ablation surface was higher than $2000^{\circ} \mathrm{C}$ [2]. As Figure 9a,b shows, phenolic resins were oxidized and stripped out completely by oxygen-acetylene steam and only carbon fibers remained on the surface of phenolic/C composites, the carbon fibers were easily oxidized to $\mathrm{CO}$ and $\mathrm{CO}_{2}$ to form a needle-like structure. Therefore, carbon fibers without the protection of resins matrix were easily eroded and destroyed by the hightemperature flame flow. In Figure 9e, because phenolic resins could be pyrolyzed at aerobic high-temperature conditions, many pores appeared in the ablation layer and the originally dense composite material becomes loose after ablation. However, owing to high viscosity at high temperature, $\mathrm{SiBCN}$ powder on the ablation surface could remain to protect carbon fibers under the scouring of high-temperature flame flow (Figure 9c,d). Moreover, according to the result of energy-dispersive X-ray spectroscopy (EDX), the appearance of $\mathrm{Si}, \mathrm{C}, \mathrm{O}$ and $\mathrm{B}$ elements on the residual resin matrix can indicate that $\mathrm{SiBCN}$ powder could be oxidized to $\mathrm{SiO}_{2}$ and $\mathrm{B}_{2} \mathrm{O}_{3}$. Meanwhile, the chemical structure of residue left on the surface of the $\mathrm{SiBCN}$-phenolic/C composites was further characterized by XPS. Comparing to Figure 3a,c, four peaks were shown in the Figure 10b: (1) $101.20 \mathrm{eV}: \mathrm{Si}_{3} \mathrm{~N}_{4}$ (Si 2p $3 / 2$ ) [21]; (2) $102.60 \mathrm{eV}: \mathrm{SiC}(\mathrm{SiC} / \mathrm{BN})\left(\mathrm{Si} 2 \mathrm{p}_{3 / 2}\right.$ ) [22]; (3) $100.20 \mathrm{eV}: \mathrm{SiC}$ (Si 2p) [22]; (4) $103.70 \mathrm{eV}: \mathrm{SiO}_{2} /\left(\mathrm{SiC}+\mathrm{SiO}_{2}\right)\left(\mathrm{Si}_{2} \mathrm{p}_{3 / 2}\right)$ [30]. Three peaks were shown in the Figure $9 \mathrm{a}$ : (1) $190.30 \mathrm{eV}: \mathrm{BN}$ (B $1 \mathrm{~s}$ ) [21]; (2) $192.20 \mathrm{eV}: \mathrm{BCN}$ (B $1 \mathrm{~s}$ ) [28]; (3) 193.20: $\mathrm{B}_{2} \mathrm{O}_{3}$ (B $1 \mathrm{~s}$ ) [31]. This result further proved the oxidation of $\mathrm{SiBCN}$ on the surface of $\mathrm{SiBCN}-$ phenolic/C composites. The occurrence of oxidation reaction of $\mathrm{SiBCN}$ powder consumed oxygen to slow down oxyacetylene flame erosion of phenolic resins and carbon fibers. The volatilization process of $\mathrm{SiO}_{2}$ and $\mathrm{B}_{2} \mathrm{O}_{3}$ was endothermic, and the volatilized outward airflow will reduce the erosive strength of the oxyacetylene heat flow [6,11]. Moreover, as shown in Figure $9 \mathrm{f}$, compared with phenolic composites during the ablation process, the ablation layer of SiBCN-phenolic/C composites had the tighter links between closely woven carbon fibers and fewer large cavities. Three reasons mentioned above could improve the ablation resistance of SiBCN-phenolic/C composites. 


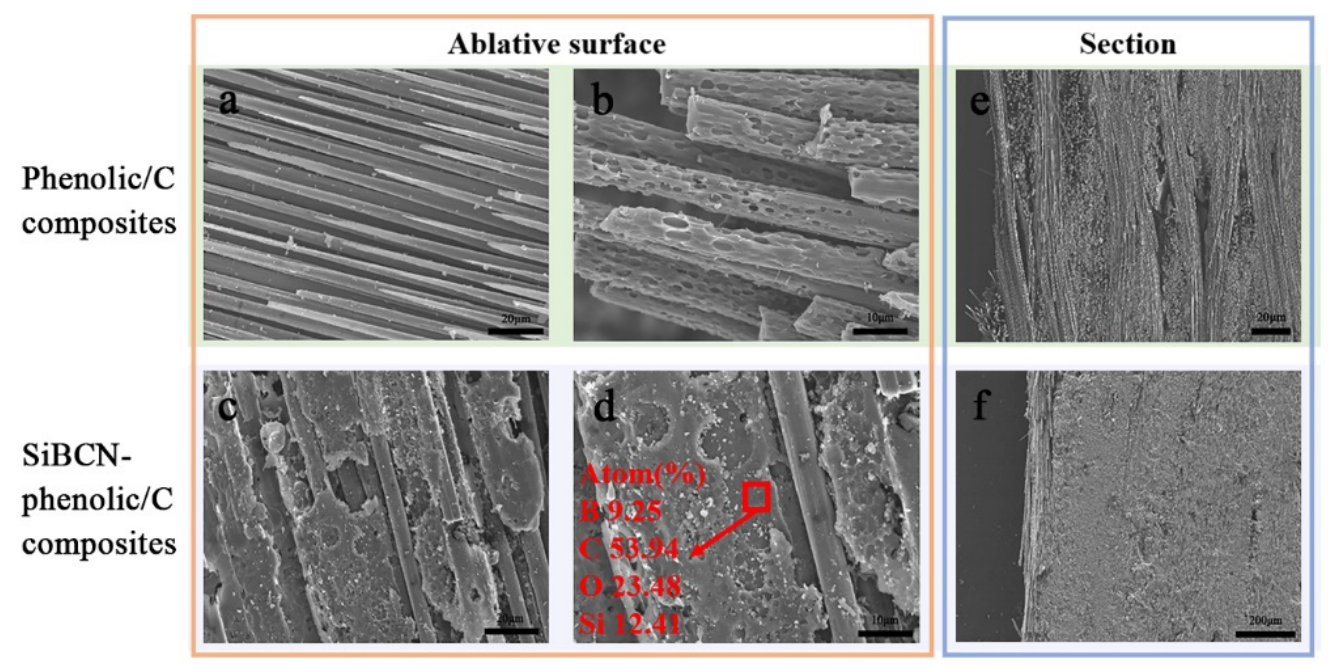

Figure 9. SEM images of the surface (a,b) and the section (e) for the ablated phenolic/C composites, SEM images of the surface (c,d) and the section (f) for the SiBCN-phenolic/C composites.
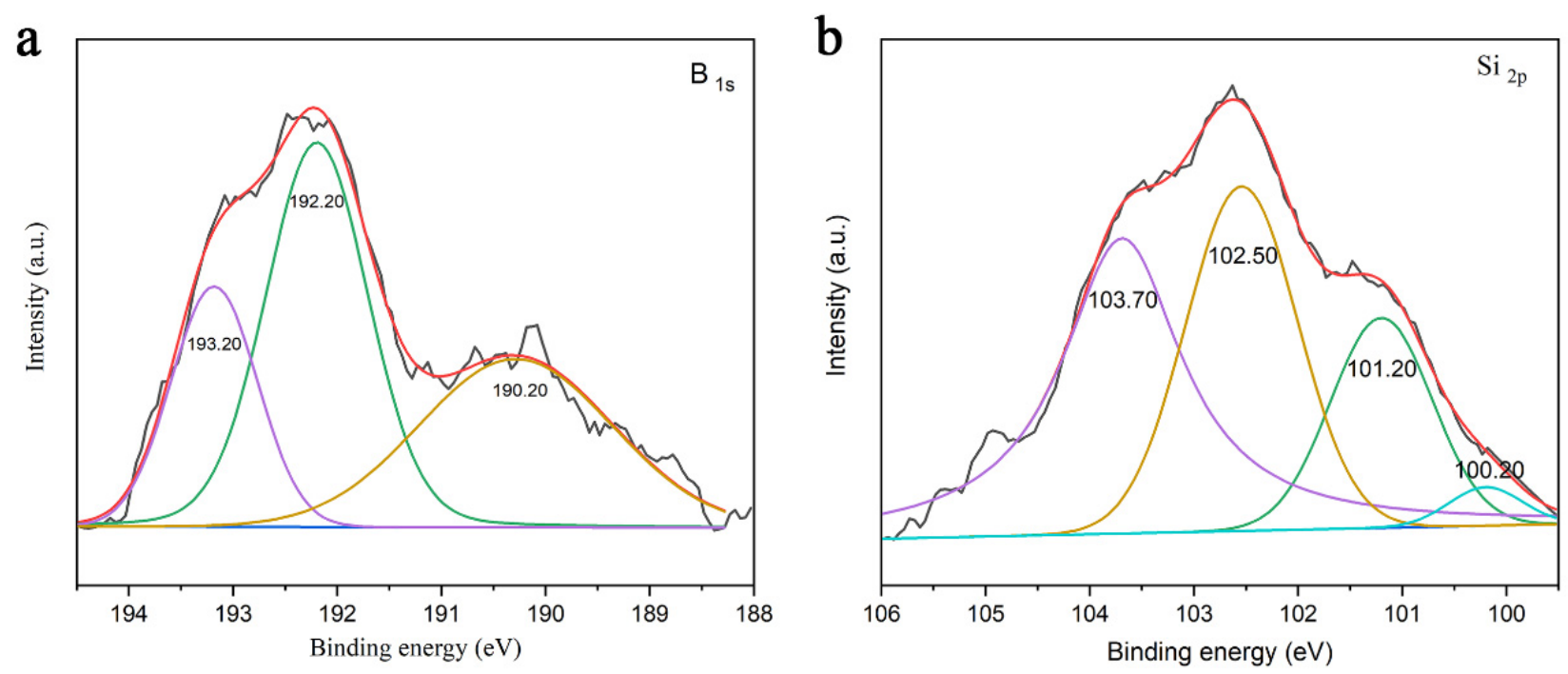

Figure 10. $\mathrm{B}_{1 \mathrm{~s}}$ spectra (a) and $\mathrm{Si}_{2 p}$ spectra $(\mathbf{b})$ of products on the surface of the ablated SiBCN-phenolic/C composites.

Temperature curves of the back surface of the SiBCN-phenolic/C composites and phenolic/C composites were shown in Figure 11. During the ablation process, the temperature increasing rate of the SiBCN-phenolic/C composites was slower than that of the phenolic/C composites. The different results between SiBCN-phenolic/C composites and phenolic/C composites were listed below. Firstly, the thermal insulation of SiBCN was high because of the amorphous structure, which can hinder heat spread [32]. Secondly, the oxidation reaction of SiBCN powder and volatilization of oxide could consume the quantity of heat, which can reduce the diffusion of heat flow into the matrix.

To illustrate the ablation resistance of phenolic and SiBCN-phenolic/C composites, a simple schematic diagram (Figure 12) was composed on basis of the above analysis. For SiBCN-phenolic/C composites, SiBCN powder with large particle sizes accumulated between the layers of carbon fiber fabric and the small particle size powder embedded in carbon fiber after preparation. In the ablation process, phenolic resins on the surface were pyrolyzed easily and SiBCN powder was reserved under the scour of oxyacetylene flame flow because of their high melt-viscosity. With the erosion of oxyacetylene, the reserved $\mathrm{SiBCN}$ powder was oxidized to $\mathrm{B}_{2} \mathrm{O}_{3}$ and $\mathrm{SiO}_{2}$. The formation and volatilization of $\mathrm{B}_{2} \mathrm{O}_{3}$ and $\mathrm{SiO}_{2}$ can consume heat and slow down the erosion rate of flame flow, which can 
alleviate the erosion of oxyacetylene flame. The oxide can adhere to the surface of SiBCN powder, preventing further oxidation. Moreover, reserved SiBCN powder and its oxides can form a protective domain to hinder the entry of oxyacetylene flame flow, so carbon fibers and resins matrix covered by $\mathrm{SiBCN}$ powder and their oxides can remain. Finally, the interior $\mathrm{SiBCN}$ powder also played an important role in preventing the oxygen from eroding further. However, without the protection of $\mathrm{SiBCN}$ powder, the surface of phenolic composites was be eroded seriously and oxygen can enter to internal deeper position, which caused high MAR and LAR.

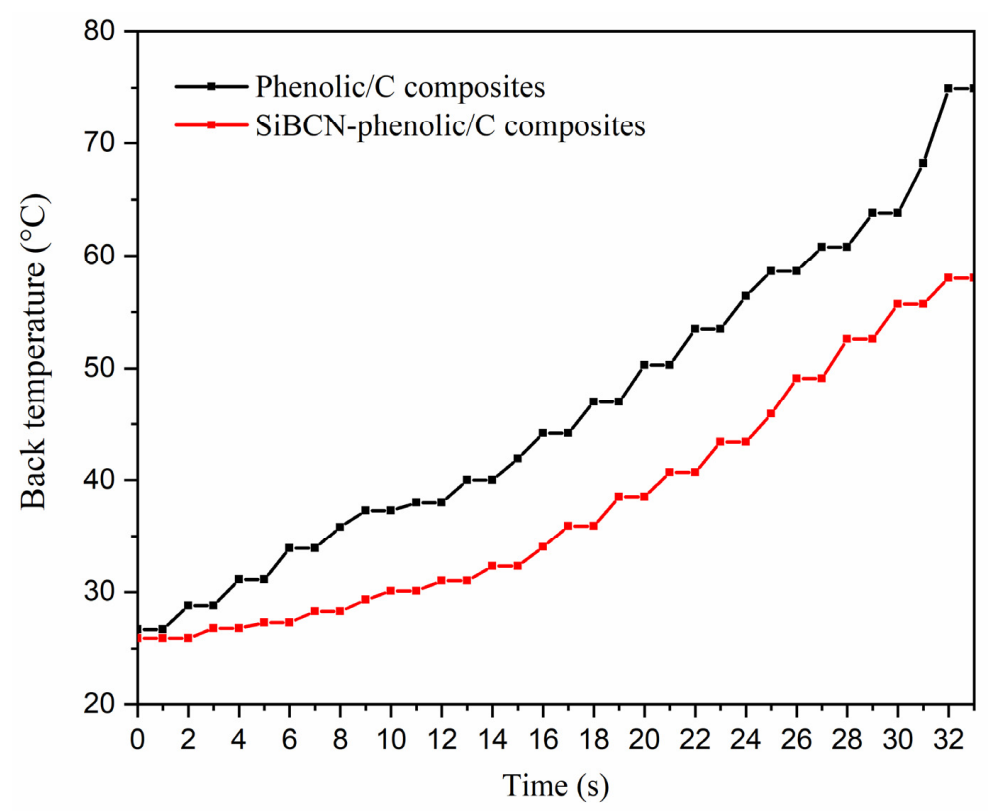

Figure 11. Back temperature of SiBCN-phenolic/C and phenolic/C composites.

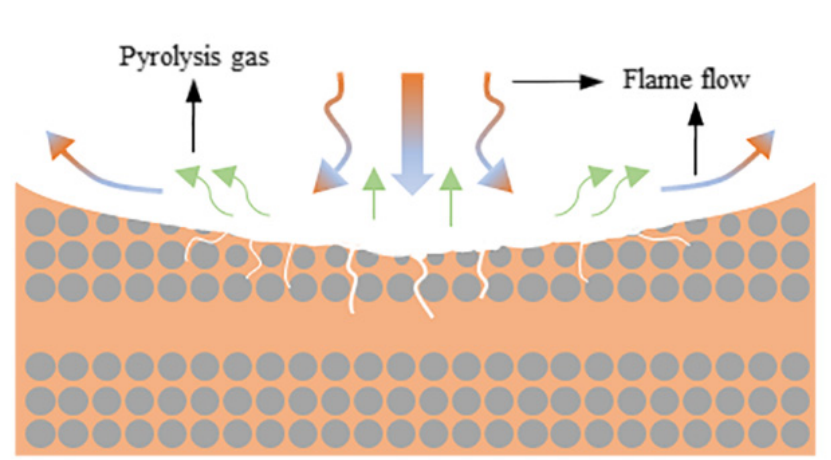

Phenolic/C composites

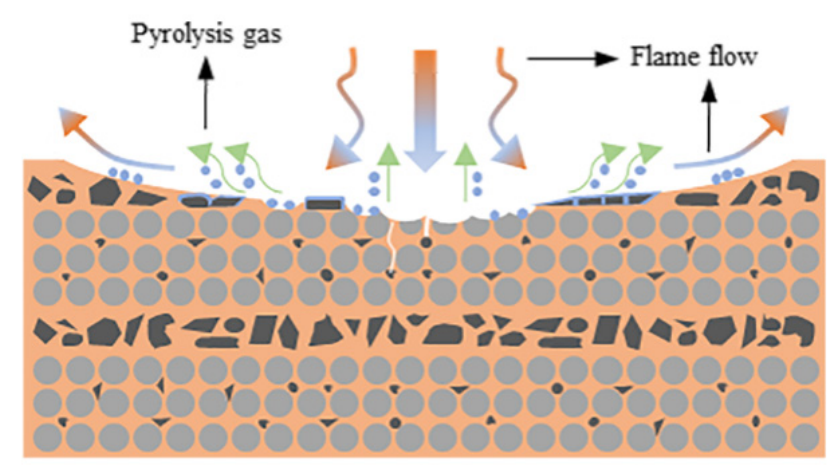

$\mathrm{SiBCN}$-phenolic/C composites

SiBCN powder $\mathrm{B}_{2} \mathrm{O}_{3} \& \mathrm{SiO}_{2} \quad$ Phenolic resin $\bullet$ Carbon fibers

Figure 12. Diagram of the ablation resistance mechanism of the phenolic/C composites and the SiBCN-phenolic/C composites.

\subsection{Mechanical Properties of the SiBCN-Phenolic/C Composites}

Figure 13a showed the interlaminar shear strengths (ILSS) for phenolic/C composites and $\mathrm{SiBCN}$-phenolic/C composites. Based on the results of the interlaminar shear test, it revealed that $\mathrm{SiBCN}$-phenolic/C composites had poorer ILSS properties as compared with phenolic/C composites. A decrease in the ILSS strength of SiBCN-phenolic/C composites can be attributed to that the effective interfacial area and fiber-resin adhesion between resins and fibers were reduced. Therefore, the load transfer capacity of the matrix decreases, which can result in lower ILSS properties [33]. As shown in Figure 13b, bending strengths of SiBCN-phenolic/C composites were higher than that of phenolic/C composites. The 
increase of bending strengths of $\mathrm{SiBCN}$-phenolic/C composites might result from that $\mathrm{SiBCN}$ powder prevented crack growth and absorbed energy [34]. However, the difference of ILSS properties and bending strengths between phenolic/C composites and SiBCNphenolic/C composites was small, so the introduction of $\mathrm{SiBCN}$ powder had little effect on the mechanical properties of composites.
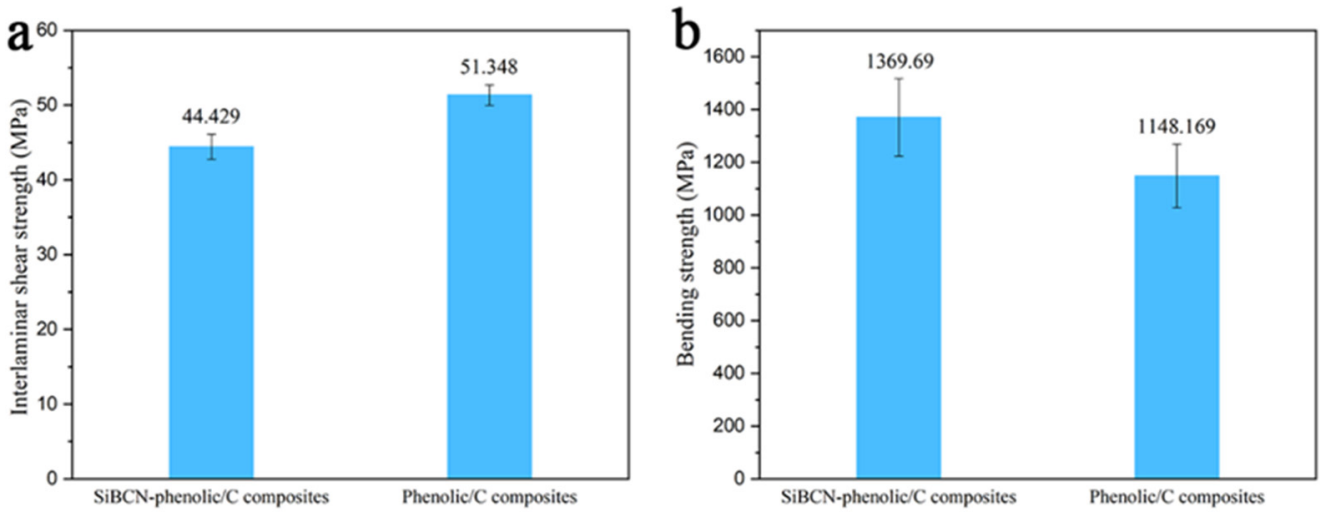

Figure 13. Interlaminar shear strength (a) and bending strength (b) of the phenolic/C composites and the SiBCN-phenolic/C composites.

\section{Conclusions}

In this paper, $\mathrm{SiBCN}$ powder with low density was introduced to phenolic resins to obtain the SiBCN-phenolic/C composites with excellent properties. Due to the introduction of SiBCN powder, the thermal stability of the cured SiBCN phenolic resins was improved. The residual constituents of $\mathrm{SiBCN}$ phenolic resins after carbonization were also investigated by XPS, and it was illustrated that the occurrence of reactions between $\mathrm{SiBCN}$ powder and pyrolysis product of phenolic resins was the main reason. The roles of SiBCN particles in improving the oxidation resistance of $\mathrm{SiBCN}$ phenolic resins and $\mathrm{SiBCN}$-phenolic/C composites were studied. For SiBCN-phenolic/C composites, the occurrence of the oxidation reaction and the formation of protective crust contributed to the improvement of oxidative resistance. The result of the oxygen-acetylene test illustrated that the LAR and MAR of phenolic/C composites reduced by $27 \%$ and $14 \%$ after the introduction of $\mathrm{SiBCN}$ powder, respectively. The improvement of the ablative property was attributed to the high viscosity of $\mathrm{SiBCN}$ at high temperature, which caused $\mathrm{SiBCN}$ powder can remain on the surface of $\mathrm{SiBCN}$-phenolic/C composites to protect the internal matrix. In addition, the oxidation of $\mathrm{SiBCN}$ powder and volatilization of oxide absorbed the energy and oxygen. Therefore, the introduction of $\mathrm{SiBCN}$ powder can enhance the thermal stability, oxidation resistance and ablation resistance of composites. In addition, the introduction of $\mathrm{SiBCN}$ powder had little effect on the mechanical properties of the composites.

Author Contributions: Data curation, W.Y.; Formal analysis, W.Y.; Investigation, W.Y. and Y.W.; Methodology, T.Z.; Project administration, H.L.; Resources, Z.L. and T.Z.; Software, H.L.; Supervision, H.L. and T.Z.; Writing—original draft, W.Y.; Writing—review \& editing, F.C. and H.L. All authors have read and agreed to the published version of the manuscript.

Funding: This research was funded by the National Natural Science Foundation of China: 51873215.

Conflicts of Interest: The authors declare no conflict of interest.

\section{References}

1. Wang, Y.; Chen, Z.; Yu, S. Ablation behavior and mechanism analysis of C/SiC composites. J. Mater. Res. Technol. 2016, 5, 170-182. [CrossRef]

2. Kumar, L.M.; Anandapadmanabhan, E.N.; Chakravarthy, P. Investigative studies on the critical prepreg variables influencing the functional performance of ablative composites for extreme environments in launch vehicles and re-entry missions. Mater. Res. Express 2019, 6, 085613. [CrossRef] 
3. Yuan, W.; Chen, F.; Li, S.; Du, Y.; Luo, Z.; Sun, Y.; Li, H.; Zhao, T. Synthesis of Silicon Hybrid Phenolic Resins with High Si-Content and Nanoscale Phase Separation Structure. Processes 2020, 8, 1129. [CrossRef]

4. Babu, T.G.; Devasia, R. Boron-Modified Phenol Formaldehyde Resin-Based Self-Healing Matrix for Cf/Siboc Com-posites. Adv. Appl. Ceram. 2016, 115, 457-469. [CrossRef]

5. Cheon, J.H.; Shin, E.S. Assessment of the ablation characteristics of carbon/phenolic composites using X-ray microtomography. Compos. Sci. Technol. 2019, 182. [CrossRef]

6. Chen, Y.; Chen, P.; Hong, C.; Zhang, B.; Hui, D. Improved ablation resistance of carbon-phenolic composites by introducing zirconium diboride particles. Compos. Part. B Eng. 2013, 47, 320-325. [CrossRef]

7. Ma, Y.; Yang, Y.; Lu, C.; Wen, X.; Liu, X.; Wu, S.; Lu, K.; Yin, J. Enhanced thermal resistance of carbon/phenolic composites by addition of novel nano-g-C3N4. Compos. Sci. Technol. 2019, 180, 60-70. [CrossRef]

8. Asaro, L.; Manfredi, L.; Rodriguez, E. Study of the ablative properties of phenolic/carbon composites modified with mesoporous silica particles. J. Compos. Mater. 2018, 52, 4139-4150. [CrossRef]

9. Daniel, A.; Badhe, Y.; Srikanth, I.; Gokhale, S.; Balasubramanian, K. Laser Shielding and Thermal Ablation Characteristics of Resorcinol Formaldehyde/Boron Nitride Composites for Thermal Protection Systems. Ind. Eng. Chem. Res. 2016, 55, 10645-10655. [CrossRef]

10. Amirsardari, Z.; Aghdam, R.M.; Salavati-Niasari, M.; Shakhesi, S. Preparation and Char-acterization of Nanoscale Zrb2/CarbonResol Composite for Protection against High-Temperature Corrosion. J. Therm. Anal. Calorim. 2015, 120, 1535-1541. [CrossRef]

11. Ding, J.; Huang, Z.; Qin, Y.; Shi, M.; Huang, C.; Mao, J. Improved ablation resistance of carbon-phenolic composites by introducing zirconium silicide particles. Compos. Part. B Eng. 2015, 82, 100-107. [CrossRef]

12. Ding, J.; Yang, T.; Huang, Z.; Qin, Y.; Wang, Y. Thermal stability and ablation resistance, and ablation mechanism of carbonphenolic composites with different zirconium silicide particle loadings. Compos. Part. B Eng. 2018, 154, 313-320. [CrossRef]

13. Izumi, A.; Shudo, Y.; Shibayama, M.; Yoshida, T.; Miyata, N.; Miyazaki, T.; Aoki, H. Interfacial Cross-Link Inhomogeneity of a Phenolic Resin on a Silica Surface As Revealed by X-ray and Neutron Reflection Measurements. Macromology 2020, 53, $4082-4089$. [CrossRef]

14. Gottardo, L.; Bernard, S.; Gervais, C.; Weinmann, M.; Miele, P. Study of the Intermediate Pyrol-ysis Steps and Mechanism Identification of Polymer-Derived Sibcn Ceramics. J. Mater. Chem. 2012, 22, 34. [CrossRef]

15. Sarkar, S.; Gan, Z.; An, L.; Zhai, L. Structural Evolution of Polymer-Derived Amorphous Sibcn Ce-ramics at High Temperature. J. Phys. Chem. C 2011, 115, 24993-25000. [CrossRef]

16. Ge, K.; Ye, L.; Han, W.; Han, Y.; Xu, C.; Zhao, T. Si(B)Cn-Doped Carbon Nanofibers with Excellent Ox-idation Resistance. Mater. Lett. 2013, 112, 124-128. [CrossRef]

17. Viard, A.; Fonblanc, D.; Lopez-Ferber, D.; Schmidt, M.; Lale, A.; Durif, C.; Balestrat, M.; Rossignol, F.; Weinmann, M.; Riedel, R.; et al. Polymer Derived Si-B-C-N Ceramics: 30 Years of Re-search. Adv. Eng. Mater. 2018, 20, 10. [CrossRef]

18. Riedel, R.; Ruswisch, L.M.; An, L.; Raj, R. Amorphous Silicoboron Carbonitride Ceramic with Very High Vis-cosity at Temperatures above $1500{ }^{\circ} \mathrm{C}$. J. Am. Ceram. Soc. 1998, 81, 3341-3344. [CrossRef]

19. Tang, Y. Synthesis of Polyborosilazane and Composition and Structure of the Pyrolyzed Products. J. Inorg. Mater. 2008, 23, 525-530. [CrossRef]

20. Zhong, Y.; Jing, X.; Wang, S.; Jia, Q.-X. Behavior investigation of phenolic hydroxyl groups during the pyrolysis of cured phenolic resin via molecular dynamics simulation. Polym. Degrad. Stab. 2016, 125, 97-104. [CrossRef]

21. Goto, T.; Hirai, T. ESCA study of amorphous CVD Si3N4-BN composites. J. Mater. Sci. Lett. 1988, 7, 548-550. [CrossRef]

22. Hens, P.; Zakharov, A.A.; Iakimov, T.; Syväjärvi, M.; Yakimova, R. Large Area Buffer-Free Gra-phene on Non-Polar (0 0 1) Cubic Silicon Carbide. Carbon 2014, 80, 823-829. [CrossRef]

23. Yu, G.-E.; Edirisinghe, M.J.; Finch, D.S.; Ralph, B.; Parrick, J. Synthesis of $\alpha$-silicon nitride powder from a polymeric precursor. J. Eur. Ceram. Soc. 1995, 15, 581-590. [CrossRef]

24. Dwyer, V.M.; Richards, J.M. Exact analytical solutions and close approximations to the depth distribution function in AES and XPS. Surf. Interface Anal. 1993, 20, 271-275. [CrossRef]

25. Holt, J.B.; Munir, Z.A. Combustion synthesis of titanium carbide: Theory and experiment. J. Mater. Sci. 1986, 21, 251-259. [CrossRef]

26. Guimon, C.; Gonbeau, D.; Pfister-Guillouzo, G.; Dugne, O.; Guette, A.; Naslain, R.; Lahaye, M. XPS study of BN thin films deposited by CVD on SiC plane substrates. Surf. Interface Anal. 1990, 16, 440-445. [CrossRef]

27. Huang, Z.; Yan, F.W.; Yuan, G. A Fluorescent Carbon Nitride Nanofibrous Hydrogel for Selective Sens-ing of Cu ${ }^{2+}$. RSC Adv. 2017, 7, 1318-1325. [CrossRef]

28. Gouin, X.; Grange, P.; Bois, L.; L'Haridon, P.; Laurent, Y. Characterization of the nitridation process of boric acid. J. Alloy. Compd. 1995, 224, 22-28. [CrossRef]

29. Yang, Q.; Sha, J.; Wang, L.; Zou, Y.; Niu, J.; Cui, C.; Yang, D. Crystalline boron oxide nanowires on silicon substrate. Phys. E Low-Dimens. Syst. Nanostructures 2005, 27, 319-324. [CrossRef]

30. Lahaye, M.; Bernard, D.; Arvieu, C. Use of Auger imaging for three-dimensional visualization of interface morphology at isoconcentration. Surf. Interface Anal. 2004, 36, 900-903. [CrossRef]

31. Schreifels, J. X-Ray Photoelectron Spectroscopy of Nickel Boride Catalysts: Correlation of Surface States with Reaction Prod-ucts in the Hydrogenation of Acrylonitrile. J. Catal. 1980, 65, 195-206. [CrossRef] 
32. Liu, H.; Zhang, L.; Li, J.; Li, H.; An, G.; Li, Y.; Chen, Z. Structure and mechanical properties of HNTs/SiBCN ceramic hybrid aerogels. Ceram. Int. 2021, 47, 9083-9089. [CrossRef]

33. Ma, Y.; Yang, Y.; Lu, C.; Xiao, D.; Wu, S.; Liu, Y. Mechanical, thermal, and ablative properties between graphene oxide and graphitic carbon nitride based carbon/phenolic composites: A comparative study. Polym. Compos. 2018, 39, E1928-E1938. [CrossRef]

34. Ding, J.; Sun, J.; Huang, Z.; Wang, Y. Improved high-temperature mechanical property of carbon-phenolic composites by introducing titanium diboride particles. Compos. Part. B Eng. 2019, 157, 289-294. [CrossRef] 